\title{
10. The structure, form and language of international environmental norms - from absolute to relative normativity
}

Niko Soininen

\section{INTRODUCTION}

International law has a dual nature. ${ }^{1}$ On the one hand it is based on formalist premises of law creation and interpretation. According to the formalist conception, law is created and changed by treaties portraying state will ${ }^{2}$ and interpreted prima facie in the light of linguistic formulations of norms contained in legal sources created in this way. Endorsing formalism, article 38 of the Statute of the International Court of Justice states that international conventions, custom recognised by the civilized nations and international legal principles shall be applied as sources of law by the International Court of Justice. ${ }^{3}$ Formalism as an interpretative paradigm gains support from article 31(1) of the Vienna Convention on the Law of Treaties (VCLT), which states that a treaty shall be interpreted in good faith and in accordance with the ordinary meaning to be given to the terms of the treaty.

On the other hand international law is instrumental. According to the instrumental conception, legal validity is based - in addition to formal validity - on legitimacy and effectiveness. Law is purposive and uses form as a vehicle for advancing certain objectives. Consistently with this, the discussions about new instruments of governance, soft law, jus cogens and obligations erga omnes are reflections of legal instrumentalism. In ways similar to formalism, instrumentalism as an interpretative paradigm gains support from article 31(1) of the VCLT, which states that a treaty has to be interpreted - in addition to its wording - in light of its object and purpose. The difficulties associated with the construction of object and purpose objectively in legal interpretation make them susceptible to considerations of equity and justice. ${ }^{4}$

Environmental law is one of those areas of law which troubles formalists. ${ }^{5}$ Much of the recent discussion within the field has revolved around governance and the function of soft law. From a formalist perspective this means that political discussions have taken over some of 
law's domain. ${ }^{6}$ As a consequence, 'we find ourselves adrift in everwidening circles of increasing uncertainty'. ${ }^{7}$ From an instrumental perspective one could argue that we also find ourselves in ever-widening circles of wicked environmental problems such as climate change and declining biodiversity which have to be addressed internationally. Legal certainty is of no avail if there is no earth to inhabit. ${ }^{8}$ Questions of lex lata and lex ferenda - law and non-law - become blurred in the context of environmental law. This is because the protection of the quality of the environment aimed at in formal legal instruments may, in the face of scientific uncertainty and new insights, require measures beyond those originally agreed upon by the contracting states. Instrumentalism is deeply embedded in environmental law as a legal discipline. Nevertheless formalism remains an important safeguard for reaching environmental objectives. ${ }^{9}$ Environmental law is both formal and instrumental.

The purpose of this chapter is to study the doctrinal importance of how legal norms are structured in formally binding instruments - hard law and in non-binding instruments - soft law. The main argument is that not only the problems of natural language but also the diversity of rules of interpretation corrode the normativity of formal law. The interpretatively constructed indeterminacy of formally binding legal norms causes unbearable softness of hard law. ${ }^{10}$ In contrast, soft law can gain legal significance as a result of either wide acceptance - legitimacy - or of effectiveness in actual state practice, even if it lacks formal validity. ${ }^{11}$ This is here described as the unbearable hardness of soft law. The weakening of formal validity and the strengthening of legitimacy and effectiveness as the criteria of normative validity lead to the conclusion that the normativity of international environmental norms is somewhat relative. The structure, form and language of international environmental law create a space in which the normativity of international environmental norms oscillates. ${ }^{12}$

\section{THE UNBEARABLE SOFTNESS OF HARD LAW}

\section{The Softness of Language}

Law is embedded in natural language in which it is created, changed and debated. Language is open textured to the extent that it usually does not convey completely unequivocal meanings from the law maker to the interpreter. ${ }^{13}$ As Hart states, "there is a limit, inherent in the nature of language, to the guidance which general language can provide' ${ }^{14}$ This fundamental feature of law makes all aspects of law more or less relative 
and thus a matter of interpretation. As a consequence, legal disputes are often about the meaning of the text of a treaty. This is why the text can function only as the starting point of legal reasoning. ${ }^{15}$

The open texture of language is a well-known feature of international environmental law. ${ }^{16}$ For example, the framework conventions relating to ozone, biodiversity and climate are formally binding instruments but they contain few clear legal rules. ${ }^{17}$ According to article 2(1) of the Vienna Convention on the Protection of the Ozone Layer, parties to the Convention shall take appropriate measures in accordance with the Convention to protect human health and the environment against the adverse effects resulting or likely to result from human activities which modify or are likely to modify the ozone layer. Despite the precautionary approach embedded in the provision and the obligatory form of the words 'shall take measures', the particular measures to be taken are left mainly to the discretion of the member state. This is because no specific measures have been identified. ${ }^{18}$ The Convention mainly includes only procedural obligations to cooperate and to adopt appropriate legislation in mitigating the depletion of the ozone layer.

A second case in point is the Convention on Biological Diversity. According to article 1 the overarching aim of the Convention is to pursue conservation of biological diversity, sustainable use of its components and fair and equitable sharing of the benefits arising from the utilisation of genetic resources. Vague and seemingly conflicting objectives are facilitated into the substantive provisions of the Convention. Under article $6(1)$, the contracting parties are obliged to develop national strategies, plans and programmes for the conservation and sustainable use of biological diversity in accordance with their particular conditions and capabilities. This obligation is, however, subject to the test of possibility and appropriateness. Similarly, according to articles 8(1) and 9(1), the parties are obliged - as far as possible and appropriate - to establish a system of protected areas and adopt measures for in situ and, to a lesser extent, ex situ conservation. Here, despite the binding formulation 'shall', the normativity of obligations is weakened by the reference to criteria that are contextual and state specific. The implementation of the obligation is thus left to the discretion of the contracting state. ${ }^{19}$

The same is true of the United Nations Framework Convention on Climate Change (UNFCCC). Under article 2, the overall objective of the UNFCCC is the stabilisation of greenhouse gas concentration in the atmosphere at a level that would prevent dangerous anthropogenic interference with the climate system. This should be done facilitating economic development simultaneously. Article 4 imposes these commitments and transforms them into normative commitments: 
- to develop, update and make available to the Conference of the parties inventories of anthropogenic emissions

- to implement national programmes to mitigate climate change

- to cooperate in the development and diffusion of technology.

These commitments are weakened normatively by state-specific criteria that are left largely unspecified. This is because the relevant practices and processes are subject to the national and regional development priorities, objectives and circumstances of each state. ${ }^{20}$

Based on the above examples, international treaties often specify only the 'least common denominators' when they seek to clarify the minimum obligations of the negotiating states. Effectively this approach requires the states to clarify, elaborate and implement unclear concepts at some time in the future. ${ }^{21}$ This manifests, first, as the willingness of states to tackle environmental problems coupled with a reluctance to adopt measures that would infringe substantially on their sovereignty and their legal competence to use natural resources to produce economic and social welfare. ${ }^{22}$ From this perspective the use of open-textured language can be seen as deliberate and functional by allowing legal institutions to develop dynamically and to address problems as they arise in the future. ${ }^{23}$ From an interpretative perspective, however, the soft formulation of legal norms weakens the legal obligations contained in formally binding treaty law. Open-textured language is the first mechanism through which hard law is softened. ${ }^{24}$ The second, and more severe mechanism for the softening of hard law is structural. The interpretative dance of formalism and instrumentalism makes the softening of hard law a necessary characteristic of law even in cases where language would not seem to leave any leeway for interpretation. The attention turns next to this softness of structure.

\section{The Softness of Structure}

Koskenniemi has argued that, while language as a medium creates certain problems, there is a much deeper and more severe reason for the indeterminacy of international law. Law unites 'an instrumentalist logic, one that looks for the realization of the objectives through law, with a formalist logic, one that establishes standards of behaviour'. ${ }^{25}$ These two overarching paradigms of legal validity and of interpretation create a 'constant push and pull' in international law. ${ }^{26}$ As a consequence the structure or the fabric of law is open textured: ${ }^{27}$ 
The dilemma of rules and standards undermines the ability of the mode of control to establish behavioural hierarchies by reference to the 'lawful'/ 'illegal' scheme. It pits 'law' against 'justice' in a fashion that reverses the hierarchy between the two. We have recourse to law in the control of social behaviour precisely to avoid reference to principles of justice, undemonstrable and open to misuse by those in power. If now we are required to know justice before we can know the law, then we must either give up the ideal of control or assume that justice is not so subjective and undemonstrable after all. ${ }^{28}$

The ontological plurality of law - that is the relationship between formalism and instrumentalism - leads to two conclusions. First, there cannot be clear and unambiguous criteria for recognising valid legal norms from invalid legal norms. Second, even when everyone would agree on the validity or the hard normativity of the norm, the question of what the rule requires - what is the content of rights and obligations emanating from it - remains open. Positive law can be interpreted through plain meaning, contextual or systemic meaning, historical meaning or teleological meaning. Doctrinal methods cannot be reduced to a single rule of interpretation. ${ }^{29}$ This, however, immediately causes a problem. If interpretative methods cannot be reduced to one or be placed in a strict hierarchy, there is always a choice to be made in interpreting the law. In other words, it is always possible to interpret formal law from an instrumentalist perspective. Formalism becomes injected with instrumentalism through one or other mode of interpretation.

Law is a thoroughly interpretative phenomenon and the rules of interpretation in international law facilitate a pluralist definition of normativity. As Koskenniemi states, 'there are no rules on when to apply a literal and when dynamic interpretation, when to give recourse to party will and when to the instrument's object and purpose'.$^{30}$ A metaphorical example may be helpful. According to Russell, when we look at a table a law - it is possible to view it as both smooth and rough - precise and imprecise in legal parlance - at the same time. But this depends on whether we look at it with our bare eyes or through a microscope: that is formalism or instrumentalism. According to Russell, it is arbitrary to claim that one or the other is the essential or the real characteristic of the table - the law. ${ }^{31}$ Remove instrumentalism through the front door - the question of validity - and it will come back through the back door - with rules of interpretation. This results in the structural indeterminacy of law.

The struggle between form and substance can be constructed as one of the structural dichotomies of legal interpretation. ${ }^{32}$ It is no surprise that, according to Koskenniemi, 'the modern programme is one of reconciliation' ${ }^{33}$ This approach includes both the acceptance and the denial of formalism and instrumentalism. Both are impossible to accept as single 
theories of law. As Peczenik notes, 'a study of classical theories of valid law leaves the reader in despair. One gets an impression the theories destroyed each other'. ${ }^{34}$ In international law the dilemma manifests itself as a conflict between, on the one hand, law as the product of the actions and the will of the state and the state being bound by those actions through pacta sunt servanda and, on the other hand, the need to create a distance between the will of the state and the law - the possibility to evaluate the actions of the state critically. As Koskenniemi explains in the context of sovereignty:

But a choice between the two positions cannot be made. The former [a fact-based view of sovereignty] ultimately ends up in apologism, affirming the State's self definition of the extent of its sovereignty. The dispute [about sovereignty] will remain unsettled. The latter [a rule-based view] will lead into utopianism, fixing the extent of sovereignty by reference to a natural, non-State related morality. Neither solution seems acceptable. Rather, both seem needed because they limit each other's negative consequences. ${ }^{35}$

The argument from structural indeterminacy becomes attractive once it is realised that formalism and instrumentalism can endlessly be pitted against each other. It becomes even more so when formalism and instrumentalism are seen to occupy both sides of a legal dispute. A formalistic argument from a treaty provision rests on the idea of treaty provisions as the highest source of information about the positive intent of the state and this intent in turn is based on the sovereignty of the state and upon pacta sunt servanda. A formalistic argument based on state sovereignty and intent can also be used against itself negatively when a state denies that the text of the treaty describes or described its actual intent. Intent visible from the text of the treaty and the 'real' intent of the state are on the opposing sides of the argument: on the one hand, the exercise of the right of sovereignty to conclude a treaty and, on the other hand, the exercise of the right of sovereignty not to be bound by a treaty that is not in line with state intent. Furthermore, a treaty may contain conflicting formal obligations which can be invoked against each other. Similarly, an instrumentalist argument from equity may be inconclusive. Formalism evokes the justice of pacta sunt servanda against the instrumentalist justice of changed circumstances. ${ }^{36}$ In these ways each side to the interpretative conflict often invokes both formalism and instrumentalism. This interplay between formal and instrumental arguments will be demonstrated in more detail in the following. 


\section{THE OPEN TEXTURE OF LANGUAGE AND LAW IN PRACTICE IN THE DANUBE DAM CASE}

\section{Introduction}

The Danube Dam case is a good illustration of the softness of hard law. Hungary and Czechoslovakia had entered into a formally binding agreement in 1977 concerning the construction and operation of the Gabcikovo-Nagymaros system of locks. According to article 1, this was a joint investment for the utilisation of the natural resources of the River Danube: mainly the production of hydroelectricity, the improvement of navigation and the protection of the quality of the water. Article 4 of the bilateral treaty stipulated that the joint project was to be concluded during the period between 1986 and 1990. Under article 5, the costs of the project were to be borne equally by the contracting states and article 8 specified that the series of locks would be jointly owned. Article 15 stipulated that the parties had to ensure that the quality of water in the Danube was not impaired as a result of the project. Under article 16, both states had to ensure uninterrupted and safe navigation in the international fairway. Article 19 specified that both parties were obliged to ensure compliance with the agreement. Following intense criticism in Hungary, the Hungarian government decided in 1989 to suspend the project due to scientific uncertainty about the environmental risks of the project. In 1991, the Slovak government decided to initiate a modified Gabcikovo project for the production of hydropower - the so-called Variant C. Hungary unilaterally terminated the treaty in $1992 .{ }^{37}$

\section{The First Issue for the International Court of Justice}

The International Court of Justice was first asked whether Hungary was entitled to abandon the project despite its treaty obligations. Hungary justified its action by relying on a circumstance of ecological necessity and accused Czechoslovakia of violation of articles 15 and 19 of the treaty concerning environmental protection. ${ }^{38}$ It further argued that the precautionary principle was a part of customary international law. ${ }^{39}$ Slovakia argued that a state of necessity was not a permissible legal ground for failing to fulfil treaty obligations and denied that it had breached its environmental obligations under the treaty. ${ }^{40}$ Hungary was advocating an instrumental approach - justice of changed circumstances - coupled with a formal argument that abandoning the project was justified under articles 15 and 19 of the treaty. Slovakia was presenting a 
formal argument that Hungary's action was inter alia contrary to articles 4,5 and 8 of the treaty coupled with an instrumental argument - justice of pacta sunt servanda.

In view of these arguments the court had to choose between the two sets of formal and instrumental arguments presented by each of the two litigants. Relying on article 33 of the International Law Commission's Draft Articles on the International Responsibility of States regarding a state of necessity, the court first concluded that a state of necessity in the form of changed circumstances was not a defence to justify withdrawing from a treaty because the environmental threat was not grave and imminent. ${ }^{41}$ This was so because the environmental damage had already occurred due to the deepening of the river prior to the treaty and Hungary had decided to engage in a formally binding treaty after this event. ${ }^{42}$ The court further stressed that, even if there had been a state of necessity, it would not have justified the unilateral abandonment of the treaty. ${ }^{43}$ The final decision could be based only on evaluative criteria without the possibility of resorting to a universal and clear legal rule. One set of formal and instrumental arguments was chosen at the expense of another set without a possibility to objectively justify this choice.

\section{The Second Issue for the Court}

The court was next asked whether the then separated Czech and Slovak federal republic was entitled to proceed with Variant C unilaterally. Hungary claimed that such unilateral actions were contrary to the treaty and other international obligations. ${ }^{44}$ In reply, Slovakia argued that its measures were in conformity with the treaty and that, even if they were not, Variant $\mathrm{C}$ could be justified as a countermeasure to Hungary's decision not to fulfil the obligations of the treaty. ${ }^{45} \mathrm{~A}$ familiar pattern of reasoning is emerging. Hungary was invoking a formalist argument based on the text of the treaty and an instrumentalist argument that treaty law should be upheld - justice of pacta sunt servanda. Slovakia was similarly invoking formal and instrumental arguments in support of its just counter measures in response to Hungary's breach of its formal obligations. Compared to the first question, the set of arguments used are reversed. This time Hungary resorted to formal arguments to uphold the treaty and justice of pacta sunt servanda while Slovakia resorted to changed circumstances and formal treaty provisions as justification for moving forward unilaterally.

The court stressed that Hungary had, in accordance with the treaty, agreed only to the joint but not to a unilateral fulfilment of the project. The court concluded that Czechoslovakia was in violation of the treaty 
when it engaged in Variant $\mathrm{C}$ unilaterally. ${ }^{46}$ The treaty did not justify unilateral action. ${ }^{47}$ The court went on to state that unilateral actions involving Variant $\mathrm{C}$ were disproportionate to the damage caused by Hungary depriving it of the right to an equitable and reasonable share of the natural resources of the River Danube. ${ }^{48}$ Formal and instrumental arguments once again underpinned the decision of the court. The breach of the treaty did justify some counter measures but the development of Variant $\mathrm{C}$ was disproportionate. The court adopted a subtle line of reasoning for not having to choose conclusively between either set of arguments put forward by the parties. The justification was in this way both formal and instrumental.

\section{The Third Issue for the Court}

The court was then asked what were the legal effects of the notification with which Hungary unilaterally terminated the treaty. ${ }^{49}$ Hungary presented five arguments - some already familiar - in support of the lawfulness and effectiveness of the notification and of the termination of the treaty:

- state of necessity

- impossibility of performance of the treaty

- fundamental change of circumstances

- material breach of the treaty by Czechoslovakia

- the development of new norms of environmental law - for example an obligation owed erga omnes for precaution. ${ }^{50}$

The second, third and fourth claims amounted to a formalist argument based on treaty law and an instrumentalist argument from pacta sunt servanda. The first and fifth claims were based on an instrumentalist argument based on changed circumstances and on scientific uncertainty but supported by formalist arguments from treaty and customary law.

The court concluded that the first argument was not a ground for the termination of a treaty even if a state of necessity did exist. ${ }^{51}$ The second argument was not compelling as the treaty did contain provisions for readjusting the project if performance in line with the treaty proved impossible. ${ }^{52}$ Similarly, the court dismissed the third argument because the political and ecological circumstances at hand were not completely unforeseen. Furthermore, articles 15, 19 and 20 of the treaty would have facilitated changing the treaty. ${ }^{53}$ The fourth argument was rejected because the unilateral termination of the 1977 treaty took place prior to Czechoslovakia's illegal actions - the declaration to terminate the treaty 
in May and the diversion of waters in October 1992. The court noted that the construction of Variant $\mathrm{C}$ itself was not contrary to the treaty. ${ }^{54}$ The court concluded that both parties had agreed to take environmental concerns seriously but they could not deviate from the principle of pacta sunt servanda. Environmental obligations had to be fulfilled within the confinements of the treaty. The notification of termination made by Hungary did not have legal effect. ${ }^{55}$

\section{The Final Issue for the Court}

Finally, the court was asked what legal consequences would follow from its response to these three questions. In deciding this question the court took into account that the treaty was in force but that interpretation of the treaty was evolving through time with the changing of factual circumstances. The court gave weight to a series of events that had already taken place when the court reached its decision:

- the hydropower plant built by Czechoslovakia had been operational for almost five years

- it received water from a significantly smaller reservoir which was relocated to cause less harm than the original reservoir planned by the parties

- the plant was operating in a 'run-of-the-river mode' and not in peak hour mode. ${ }^{56}$

The court stated that the objectives of the treaty had been at least partially achieved as a result of the existing structures built by Czechoslovakia. ${ }^{57}$ Instrumentalism abounds within the very flexible boundaries of form. In other words, consequentialist and teleological reasoning allows the court to adjust formal requirements and to justify this from within the formal instrument itself.

According to the court, the treaty had always been a dynamic instrument because it had been amended frequently before the escalation of the conflict. ${ }^{58}$ The conclusion of the court was that the treaty obliged the parties to negotiate only for the purpose of attaining the treaty's multiple objectives - economic use and environmental protection. ${ }^{59}$ It was not for the court to decide what the outcome of these negotiations should be. ${ }^{60}$ Pacta sunt servanda obliged the parties to ongoing negotiations without setting substantive requirements other than the objective of reconciling the different uses of the river by the two states. ${ }^{61}$ With regard to damages, the court stated that both states had committed unlawful acts under international law. This justified the decision of the court to 
encourage the parties to renounce all financial claims. ${ }^{62}$ The principle of cooperation was established as the main instrument for repairing the damage caused to both parties. ${ }^{63}$

\section{The Importance of the Case}

The Danube Dam case is an example that illustrates the dance between formalism and instrumentalism in legal reasoning. ${ }^{64}$ It is also a good example of the structural inconsistencies of treaty law when treaty obligations come into conflict with each other. Instrumentalist arguments were carefully utilised when each of the parties argued for a certain normative content of treaty obligations. Hungary's refusal to fulfil its obligations under the treaty and Czechoslovakia's unilateral actions to proceed were both unlawful. Hungary's unilateral termination of the treaty was not valid as the dispute, in light of pacta sunt servanda and environmental considerations, was decided within the framework of the treaty. Both states had equally strong formal and instrumental grounds for their claims. For this reason the court could not bring itself to order the demolition of the unlawful hydropower plant or to decide the question of damages as both litigants had acted wrongfully. The procedural obligation to cooperate formed a nice halfway house which allowed the court to escape the impossibility of having to choose between formal and instrumental interpretation.

Overall, the Danube Dam case portrays two types of structural indeterminacy. First, structural indeterminacy can be a question of inconsistent rules within a treaty - formal indeterminacy. The inconsistency arises from the relationship between the right to use the environment and the obligation to protect it. ${ }^{65}$ Second, structural indeterminacy can be a question of incoherent objectives between the use and the protection of the environment - instrumental indeterminacy. ${ }^{66}$ These two mechanisms create structural softness in environmental treaty law and this softness in turn weakens the normativity of obligations contained therein. The formal validity of an international treaty cannot enshrine its norms with hard normativity if the formal and instrumental structure of norms fails to uphold this normativity.

The conclusion that softness of hard law causes it to be less normative is a controversial claim. Weil has argued that a "rule of treaty or customary law may be vague, "soft"; but, as the above examples show, it does not thereby cease to be a legal norm' ${ }^{67}$ The argument presented here is not, however, that norms in formally binding instruments lose their validity due to their indeterminacy. The argument here is epistemological. It is not that unclear hard law would not be law but that 
it is impossible to know what the law requires. Decreased effectiveness robs formally valid law of some of its normativity. ${ }^{68}$

\section{THE UNBEARABLE HARDNESS OF SOFT LAW}

\section{The Normativity of Soft Law}

Formalists typically hold that there is a more or less clear line of demarcation between law and non-law - lex lata and lex ferenda - which facilitates the distinction between binding and non-binding norms. Norms that do not bind their addressees create neither legal rights nor legal obligations. From this perspective, relative normativity in the form of soft law is a mirage. Legal rights and obligations can be based only on legal sources of formal pedigree. Legal validity and normativity are not matters of degree. ${ }^{69}$ As Weil puts it, "without this positivistic approach, the neutrality so essential to international law qua coordinator between equal, but disparate, entities would remain in continual jeopardy' ${ }^{70}$ From a formalist perspective soft law and hard law are separated only by their potentially binding effect. ${ }^{71}$

The formalist challenge of separating law from other normative systems and the development of governance systems towards the penumbra of traditional conceptions of international law has forced scholars to invent new concepts which would do justice to the ever more complex normative universe of environmental law. ${ }^{72}$ Soft law, situated normatively in the twilight zone between law and politics, is one attempt to address the normative complexity of law. ${ }^{73}$ Traditionally, the concept of soft law has been an element of the open textured treaty provisions already analysed. ${ }^{74}$ Currently, the concept is used for the most part to describe legal instruments that lack formal validity but contain nonetheless normative requirements that are complied with. ${ }^{75}$

In terms of formalism and instrumentalism, soft law is something of a hybrid. It is often based on the absence of formal state consent. At the same time soft law instruments often contain normative requirements whose normative validity is based on legitimacy and effectiveness. ${ }^{76}$ Applying these two criteria, 'the hardness of soft law lies in its capacity for openness, flexibility and simplicity, which is expected to foster the coherence, unification, stability and diversity of rules of conduct, as well as speed of regulation, empirical legitimacy and low negotiation costs' ${ }^{77}$ According to Shelton, 'if states expect compliance and in fact comply with rules and principles contained in soft law instruments as well as they do with norms contained in treaties and custom, then perhaps the concept 
of international law, or the list of sources of international law, requires expansion' ${ }^{78}$ The increasing acknowledgment and development of soft law seem to imply that the functions of hard and soft law do not necessarily differ. The aim of each is to steer state actions. ${ }^{79}$

Although soft law cannot by definition be formally binding, formalism as the singular theory of normativity is being increasingly challenged. Instead of a binary category of binding and non-binding norms, legal validity becomes a question of degree. The test for separating legal norms from other norms is not as straightforward as formalism requires.

\section{Towards Relative Normativity}

According to Shelton the expansion of normativity is based on three trends in international environmental policy and law. First, there is the relationship between treaty law and customary international law. One major governance challenge for many environmental problems is that treaty law is prima facie binding only on states parties to the treaty, unless norms embedded in the treaty can be seen to form a part of customary international law. This creates an incentive for some states to withdraw from formally binding environmental agreements if this would advance their economic goals at the expense of other states willing to comply with legal restraints. This raises the question whether these states operating as free riders can be subjected to other than formal legal requirements. Second, the expanded scope of international law, the recognition of the interests of non-state actors as well as those of state actors, and the increasing use of codes of conduct and other soft law instruments challenge the traditionally clear boundaries between law and non-law. Third, peremptory norms and general international obligations in the field of international criminal law challenge the formal idea of normativity based on state consent. ${ }^{80}$

It has already been noted that soft law norms lack formal validity. This means that whatever normativity they may have relies on the norm's legitimacy and effectiveness. Soft law does not merit any legal status if these criteria are not fulfilled. For this reason there remains a considerable area of environmental governance occupied by politics even if the concept of law is expanded to include non-formal criteria. The 1972 Stockholm Declaration, the 1982 World Charter for Nature and the 1992 Rio Declaration are good examples of normative instruments which do not form law properly so-called. This is so even if they were and are influential in the development of international environmental law. Lack of formal validity, vagueness of instrumental language and lack of effectiveness suggest policy goals rather than legal norms. 


\section{Soft Law in Practice}

\section{(a) Introduction}

The softness of the Stockholm Declaration, the World Charter for Nature and the Rio Declaration can be contrasted to instruments which regardless of their lack of formal validity - can be seen to create legal obligations based on their legitimacy and effectiveness. ${ }^{81}$ From a formal perspective this unbearable hardness of soft law manifests itself, inter alia, in these examples:

- the status of United Nations General Assembly resolutions regarding driftnet fishing

- the status of the World Bank Nile Basin Initiative

- the status of the Clean Development Mechanism

- the status of non-binding guidance documents in the European chemical governance framework (REACH).

\section{(b) Driftnet fishing}

After rising international concern over unsustainable fishing in the high seas and in the exclusive economic zones, the UN General Assembly adopted several resolutions purporting to ban driftnet fishing globally. ${ }^{82}$ In article 4(a) of the 1989 Resolution, the UN General Assembly stated that a moratorium on all large scale pelagic driftnet fishing should be imposed by the end of June $1992 .{ }^{83}$ In 1990 the General Assembly further expressed concern over the unsustainability of driftnet fishing leading to the adoption of Resolution 46/215 in 1992 with substantive requirements for national implementation and enforcement for the banning of driftnet fishing: ${ }^{84}$

Recognizing that a moratorium on large-scale pelagic drift-net fishing is required, notwithstanding that it will have adverse socio-economic effects on the communities involved in high seas pelagic drift-net fishing operations ... Calls upon all members of the international community to implement resolutions $44 / 225$ and $45 / 197$ by ... [ensuring] that a global moratorium on all large-scale pelagic drift-net fishing is fully implemented on the high seas of the world's oceans and seas, including enclosed seas and semi-enclosed seas, by 31 December $1992 .{ }^{85}$

Because the resolutions were adopted by consensus, imposed clear normative requirements on all members of the international community and were adopted by a large number of states, some commentators have concluded that the ban on using drift nets may reflect a rule of customary international law. ${ }^{86}$ The effectiveness of these UNGA resolutions has 
been well documented. ${ }^{87}$ One major factor in securing compliance with the resolutions was that the United States was strongly driving a moratorium on driftnet fishing. This was supported by a threat that a failure to comply with the resolution could have resulted in trade sanctions imposed by the US on any state which failed to comply. ${ }^{88}$ The legitimacy of international concern over the well-being of fisheries coupled with effective political consequences for non-compliance and supported by the clear language and structure of the resolution led to the acknowledgment of specific legal obligations regardless of the lack of formal validity.

\section{(c) The Nile Basin Initiative}

A second example of hard soft law is the World Bank sponsored Nile Basin Initiative (NBI) - a regional and inter-governmental partnership formed by ten riparian states adjacent to the River Nile. The initiative provides, inter alia, for the joint management and planning of Nile Basin water resources. ${ }^{89}$ The NBI is an overarching strategic action plan which is divided into seven Shared Vision Programmes and Subsidiary Action Programmes. It aims at developing the Nile's water resources in an equitable and sustainable way: by ensuring efficient water management and cooperation; by targeting poverty eradication; and by ensuring effective implementation of mutually agreed objectives. The NBI has been largely responsible for changing a culture of competition over scarce water resources into a culture of mutual benefit and cooperation. ${ }^{90}$ This was originally managed under a non-legally binding instrument the NBI - which enjoyed considerable legitimacy among the Nile riparian states. ${ }^{91}$ Following the informal NBI, the Nile riparian states are in the process of adopting a formally binding agreement - the Cooperative Framework Agreement ${ }^{92}$ - for the governance of the Nile river basin. ${ }^{93}$ From this perspective the NBI can be seen to have had an important catalytic effect in moving towards a binding and more permanent framework. ${ }^{94}$

\section{(d) International carbon markets and the clean development mechanism}

A third example can be taken from international climate law. The clean development mechanism (CDM) is one of the tools designed to mitigate climate change under the UNFCCC framework. The basic idea of the mechanism is to allow countries with carbon emission reduction targets under the Kyoto Protocol - that is Annex I countries - to implement projects resulting in reduced emissions in developing countries. ${ }^{95}$ Although the CDM is formally based on article 12 of the Kyoto Protocol, 
it is normatively shaped at the international level by the Marrakesh Accords ${ }^{96}$ as well as the decisions of the CDM Executive Board. This governance framework is further complemented by host and purchasing country regulations as well as voluntary standards such as the CDM Gold Standard. ${ }^{97}$ Hard law and soft law instruments form a concerted effort to regulate global carbon markets. Here, soft law plays an important function in the interpretation and implementation of article 12 of the Kyoto Protocol. As Kulovesi summarises:

All this goes to show that what was originally a provision in an international treaty has become a dynamic regulatory process that involves not only sovereign states that are Parties to the Kyoto Protocol, but also the CDM Executive Board, the UNFCCC Secretariat, national CDM authorities, private sector and civil society actors, local stakeholders as well as donor countries and organizations. ${ }^{98}$

Interestingly, and opposite to the NBI discussed above, the governance framework around CDM displays a regulatory development moving from formally binding requirement towards softer normative instruments fleshing out the commitments originally set out in a formally binding instrument. Soft law has a strong role to play in understanding the normative requirements forming the CDM.

\section{(e) The EU chemical governance framework}

Examples of hard soft law abound outside of international law as well. This is clearly visible, inter alia, in the EU chemical governance framework. Under a legally binding regulation concerning registration, evaluation, authorisation and restriction of chemicals (REACH), manufacturers and importers of chemicals have a legal obligation to register substances introduced into the EU to protect human health and the environment from the adverse effects of chemicals. ${ }^{99}$ Due to the highly technical and complex nature of REACH, the European Chemicals Agency has produced a set of guidance documents which aim to clarify the legal obligations imposed by the legally binding REACH for the benefit of the public. These documents are paradigmatic soft law materials with a disclaimer that the information and guidance contained in them do not constitute legal advice. ${ }^{100}$ Despite this, it is often noted that the REACH Guidance Documents have tangible legal effects in fleshing out the obligations contained in the legally binding regulation. ${ }^{101}$ In this case, formally non-binding guidance documents perform de facto an important interpretative function. Their validity is based on legitimacy and effectiveness and clearly not on formal validity. 


\section{(f) Conclusion}

These examples illustrate three distinctive normative routes which constitute and construct the heightened normativity of soft law. The UN General Assembly driftnet resolutions demonstrate how soft law becomes illustrative of customary law. ${ }^{102}$ The NBI illustrates the dynamic effect of soft law. Legitimate and effective soft law instruments, such as the NBI, can have an important catalytic effect in paving the way for formally binding instruments. ${ }^{103}$ On the other hand - and as the CDM illustrates hard law obligations can also be a starting point for further normative developments using hard and soft law in a concerted effort to address environmental problems such as climate change. Furthermore, the CDM on the international level and the REACH Guidance Documents on the European level illustrate the important interpretative effect of soft law in a situation where legally binding obligations are indeterminate, complicated or conflicting. Here soft law functions in conjunction with hard law. ${ }^{104}$ This, however, need not be the case as soft law can perform an independent steering function, as in the case of driftnet fishing and the NBI. Acting as a normative source of law, a catalyst of normative change and an interpretative aid, soft law can be seen to have the potential to create hard normative effects even if it lacks formal validity. ${ }^{105}$

\section{SUMMARY}

The foregoing paragraphs have analysed how a strictly doctrinal distinction between formality and informality, between binding and non-binding norms and between law and politics can often become blurred in international environmental law. There are simultaneously two trends which blur these linear distinctions. The first trend is the softening of hard law which follows from the open texture of language and structure of the law. The second is the hardening of soft law. Each is now summarised in turn.

The first trend, the softening of hard law, is a reflection of the language and of the structure of the relevant instruments. In framework conventions such as the Convention for the Protection of the Ozone Layer, the Biodiversity Convention and the Climate Change Convention, the use of vague language is often intentional in order to facilitate the recognition of the diverse environmental interests of the negotiating states. Softening of hard law, however, goes beyond language. It is partially constructed by the variety of secondary - interpretative - rules or canons which facilitate the existence of two competing interpretative paradigms - formalism and 
instrumentalism. The interplay between the two paradigms causes international environmental law to be structurally indeterminate. This has the potential effect of weakening even the clearest linguistic formulation of a norm. Lack of clarity erodes the foundations of the normativity of hard law through decreased effectiveness.

The second trend behind the blurring of normativity in international environmental law is the hardening of soft law. ${ }^{106}$ The examples from the UN General Assembly reactions to driftnet fishing, the development of a governance framework for the waters of the Nile, the governance framework surrounding the CDM and the role of guidance documents in the interpretation of the European chemicals regulation lead to the conclusion that soft law can have a direct effect on the actions of states independently of hard law. ${ }^{107}$ In addition, the existence of soft law can be an important step towards the recognition of hard law - which may be described as the catalytic effect - and it has a considerable interpretative effect when fleshing out the normative requirements of hard law. In this way soft law can have a considerable normative effect on the actions of states. As a consequence, a focus on formally binding hard law can often give only a partial and limited view of the de facto legal rights and obligations of states. Soft - non-treaty - agreements and arrangements are of legal relevance even if they lack formal validity. This is simply because 'their political function resembles that of treaties' and this provides the "parties to international arrangements with the power to "justify and persuade". ${ }^{108}$

This conclusion may, from a formal perspective, sound more dramatic than it actually is. Formal validity still plays an important role in ascertaining normativity. This analysis has sought to demonstrate that the formal source of normativity is not the only one. Legitimacy and effectiveness should be factored in as supplementary criteria. This means that the test for evaluating what international environmental law requires is an evaluation of multiple traces of normativity. These traces include formal criteria such as the formal validity of the instrument in which the norms in question are embedded, the clarity of the rights and obligations emanating from the instrument and the degree of delegation of the implementation and enforcement of the norm to a third party. ${ }^{109}$ In addition, traces of normativity include instrumental criteria based on legitimacy and effectiveness linked to the evaluation of contextual criteria in terms of aims, equity and consequences. ${ }^{110}$

The softness of hard law and the hardness of soft law challenge traditional ideas of normativity. ${ }^{111}$ The monopoly of form for the purpose of defining validity - despite its theoretical beauty and rigour - does not portray international environmental law in an accurate light. Normativity 
becomes relativised through the complementary criteria of validity. Validity is a more subtle phenomenon than the simple dichotomy between formally binding and non-binding norms - normative and non-normative - suggests. Instead of strict hierarchies, international environmental norms should be seen to inhabit a relative scale of interlinked norms which often comes much closer to a heterarchy than to a hierarchy. ${ }^{112}$ In other words, the normative structure of international environmental law is as much horizontal as it is vertical.

\section{NOTES}

1. Here applying loosely Alexy's (2010) dual nature thesis. According to Koskenniemi, international law is simultaneously concerned with facilitating state interests and their critique: see Koskenniemi (2014, p. 48).

2. This is based on the binding nature of international agreements - pacta sunt servanda - which has been endorsed in international case law at least since the Lotus case (1927, p. 18). See also Thirlway (2014, p. 93).

3. Of the formal sources, treaty law is the most significant one: see Beyerlin and Marauhn (2011, p. 265); Redgwell (2014, p. 695). To be exact, principles are not a purely formal source as they always contain an element of justice: see Dworkin (1978, p. 40). Despite this, Verschuuren (2003, p. 128) views legal principles as hard law (setting legally binding obligations).

4. See, on the problems of ascertaining purpose in interpretation in general, Weinberger (1979, pp. 142-3); Summers (1982); Peczenik (1989, pp. 353-4); Petman (2012, p. 285). Koskenniemi (2014, p. 37): 'The difficulty with the instrumentalist mindset is that there never are simple, well-identified objectives behind formal rules. Rules are legislative compromises, open-ended and bound in clusters expressing conflicting considerations'.

5. Weil (1983, p. 417): 'It is inadmissible within, say, "development law" or "environmental law", to give equal status to conventional or customary rules, on the one hand, and non-normative resolutions, on the other'.

6. See, on the discussion, Kotzé (2012), and the formalist criticism, Klabbers (1996, pp. $167-70,181)$.

7. Weil (1983, p. 428).

8. This is why ecological sustainability is often seen as a Grundnorm of environmental law: see Bosselmann (2013, pp. 83-4); Fisher (2013, p. 433). Ecological sustainability is a means of transforming the law: see Kotzé (2013, p. 136).

9. Bugge (2013, p. 7); Voigt (2013, p. 147).

10. In one sense, soft law can be used to describe indeterminate and weak obligations adopted in formally binding law: see Weil (1983, pp. 414-15, fn.7); Shelton (2014, p. 159). In this chapter I retain the term for formally non-binding norms. The concept of hard law is reserved for formally binding norms. Despite soft law's formally non-binding character, the concept has been criticised as unclear as some view law referring only to formally binding obligations. See, for a concise criticism on the concept of soft law, Friedrich (2013, p. 12).

11. See also Toope (2007, p. 114).

12. Fisher (2013 p. 224): 'It is the structure, form and language of the instruments that comprise this normative framework that constitutes the architectural jurisprudence of the system'. 
13. Aarnio, Alexy and Peczenik (1992, p. 20): '[U]nambiguity is actually rare in law texts. The normal case is for instance ambiguous, vague, evaluatively open, incomplete text of law or the case where the law text contains an internal incompatibility (or inconsistency)'.

14. Hart (1994, p. 126). See also Leiter (2001, p. 295).

15. Fisher (2013, pp. 73, 201).

16. A good example of this is the North Sea Continental Shelf case (1969) in which the ICJ stated that the equidistance principle enshrined in art.6 of the 1958 Continental Shelf Convention was not of norm creating character due to vagueness of the 'special circumstances' requirement in the provision.

17. Vihma (2013, p. 155): 'Framework conventions in international environmental law are formal, ratifiable and legally binding treaties. However, framework conventions typically do not contain clear, detailed, or specific rules that could be implemented in domestic legislation in a straightforward manner'.

18. See also Birnie, Boyle and Redgwell (2009, p. 350). The 1985 Vienna Convention was an empty framework and the ozone regime only received proper legal mechanisms with the introduction of the 1987 Montreal Protocol and following amendments to it: see ibid. (pp. 351-5).

19. Ibid. (p. 617). They do, however, highlight the importance of interpreting the treaty in light of its preambular provisions and state that the success of the treaty can only be evaluated in light of national implementation measures, and not so much based on the vague formulations of the provisions. It must also be noted that the overall obligations emanating from a legal framework can rarely be evaluated based on the treaty text alone. For instance, protective measures have been fleshed out by the Conference of the Parties (CoP) of the Convention on Biological Diversity (CBD) in later decisions: see the Work Programme on Protected Areas; https://www. cbd.int/protected/pow/learnmore/intro/. In this context hard law sets only soft obligations which get more specific in soft law. This is actually the case in both the CBD and the ozone frameworks: see Friedrich (2013, pp. 47-9, 49-51).

20. Birnie, Boyle and Redgwell (2009, pp. 359-60). See, on the early criticism of the legal weakness of the framework, Bodansky (1993, p. 454).

21. Balekjian (2015, p. 360).

22. Beyerlin (2007, p. 427).

23. Balekjian (2015, p. 358). See, on the necessarily dynamic aspects of law functioning through the 'relative indeterminacy of aim' and 'relative ignorance of fact', Hart (1994, p. 128). See also Koskenniemi (1997, p. 574); Shelton (2003, p. 7). Law is always an exercise in finding a balance between legal certainty and legitimacy (past and future): see Singer (1984, p. 11).

24. Hillgenberg (1999, pp. 500-501) argues that weak language of a formal treaty can bring it closer to formally non-binding instruments.

25. Koskenniemi $(2014$, p. 42).

26. Ibid. (p. 41).

27. Koskenniemi (2005, p. 590): 'But the claim of indeterminacy is not at all that international legal words are semantically ambivalent. It is much stronger (and in a philosophical sense, more "fundamental") and states that even where there is no semantic ambivalence whatsoever, international law remains indeterminate because it is based on contradictory premises and seeks to regulate the future in regard to which even single actors' preferences remain unsettled'. See also on a more general level Kress 2003, p. 253: 'Critical legal scholars, building on the work of legal realists, have developed an extensive array of arguments concluding that law is radically indeterminate, incoherent, and contradictory. Law is indeterminate to the extent that legal questions lack single answers. In adjudication, law is indeterminate 
to the extent that authoritative legal materials and methods permit multiple outcomes to lawsuits'.

28. Koskenniemi (1997, p. 575).

29. Many categorisations have been suggested but most of them have been unsatisfied with a single interpretative method: see MacCormick and Summers (1991, pp. 512-15).

30. Koskenniemi (1997, p. 575).

31. Russel (1998, ch.1).

32. Peczenik (1989, p. 34).

33. Koskenniemi (2005, p. 164).

34. Peczenik (1989, p. 237). See also Aarnio, Alexy and Peczenik (1992, p. 233).

35. Koskenniemi (2005, p. 239).

36. This illustration of structural indeterminacy is from Koskenniemi (1997, p. 576).

37. Danube Dam case (1997, paras 1-26).

38. Ibid. (paras 40-41).

39. Ibid. (para. 42).

40. Ibid. (paras 44-5).

41. Ibid. (paras 50-51, 54, 57).

42. Ibid. (paras 55-7).

43. Ibid. (paras 57-8).

44. Ibid. (para. 70).

45. Ibid. (para. 69).

46. Ibid. (para. 78).

47. Ibid. (para. 86).

48. Ibid. (paras 85, 87).

49. Ibid. (para. 89).

50. Ibid. (para. 92).

51. Ibid. (para. 101).

52. Ibid. (para. 103).

53. Ibid. (para. 104).

54. Ibid. (para. 108).

55. Ibid. (paras 113-15).

56. Ibid. (para. 134).

57. Ibid. (para. 136).

58. Ibid. (para. 138).

59. Ibid. (para. 139).

60. Ibid. (para. 141).

61. Ibid. (para. 142).

62. Ibid. (para. 153).

63. Ibid. (para. 150). It is no surprise that the court resorted in the end to procedural criteria as "[t]he law is for stability but equally for change, and which of its contradictory aspects is stressed cannot be determined from within the law itself': Koskenniemi (1997, p. 577).

64. Koskenniemi (1997, p. 579): 'Law continues to set up hierarchies and provide the resources for reversing them. ... never fully determined by the context (or the text) but never completely free from it either'.

65. Shelton (2014, p. 152) has argued that '[t]here are potentially numerous problems of hierarchy posed by the need to apply or balance different rights and obligations contained within a single treaty, reconcile norms and procedures in multiple treaties governing the same topic, or resolve conflicts across regimes'.

66. Taking a broader view, instrumental indeterminacy is not rare in international treaties. This is especially visible in the CBD and in the Convention on Climate Change but it is not restricted to framework conventions. The United Nations 
Convention on the Law of the Non-navigational Uses of International Watercourses contains this feature as well in the form of the principle of equitable utilisation and the 'no harm' rule. Under art. 5 of the UN Watercourses Convention, the principle of equitable utilisation is premised on the use of water resources. The starting point of the provision is utilisation, which is limited to a sustainable level. Sustainability from an environmental perspective means in this context that environmental protection measures are adequate. This requirement lessens the importance of protection measures and tips the scales toward use. Under art. 6, when assessing the substantive criteria for equitable utilisation, environmental protection and conservation are only one element to be taken into account in legal evaluation. At the same time, the 'no harm' rule protects only other watercourse states, not the environment per se. In addition, harm can be caused to the environment and to other states if it is not significant. Toope (2007, pp. 118-19) has argued that the effectiveness of the 'no harm' rule and the principle of equitable utilisation can be characterised as formally binding treaty law, which includes 'formal adjudicative procedures that were never employed'.

67. Weil (1983, p. 414). More recently, d'Aspremont (2008, pp. 1084-5) has argued in a similar vein: 'Accepting that there may be legal acts with a soft negotium means that the normative character of an act is not the prerequisite of its legal character'.

68. See also Baxter (1980, pp. 550-7).

69. Weil (1983, pp. 421, 423). Klabbers (1996, p. 181): 'Our binary law is well capable of handling all kinds of subtleties and sensitivities; within the binary mode, law can be more or less specific, more or less exact, more or less determinate, more or less wide in scope, more or less pressing, more or less serious, more or less far-reaching; the only thing it cannot be is more or less binding'.

70. Weil (1983, p. 421). According to Weil (p. 420), international law cannot carry out its function of peaceful cooperation between countries in a value-pluralistic world without being neutral.

71. Beyerlin and Marauhn (2011, p. 290).

72. Hey (2007, p. 767) observes that 'within global environmental governance formal state consent, which is pivotal to the traditional doctrine of international law, plays only a limited role'.

73. Shelton (2014, p. 138): 'It is not always clear where law ends and non-law begins, or, to use the common terminology, where "soft" law should be placed".

74. Ibid. (p. 160): "Treaty mechanisms are including more "soft" obligations, such as undertakings to endeavour to strive to cooperate. Non-binding instruments in turn are incorporating supervisory mechanisms traditionally found in hard law texts'.

75. Ibid. (p. 159): "There is no accepted definition of "soft law" but it usually refers to any international instrument other than a treaty containing principles, norms, standards, or other statements of expected behaviour'. See Friedrich (2013, pp. 3-8) for a concise description of the discussion in international law regarding soft law.

76. See Weil (1983, pp. 414-15, fn.7) arguing that some norms are not even meant to be binding in the formal sense.

77. Dorbeck-Jung and van Amerom (2008, p. 134) (emphasis in original).

78. Shelton (2014, p. 160).

79. Beyerlin and Marauhn (2011, p. 290). Shelton (2003, p. 8): 'In the international arena, law is not the only form of social control or normative claim. Other basic requirements of behaviour emerge from morality, courtesy, and social custom. They form part of the expectations of social discourse. Compliance with such norms may be expected and violations sanctioned'.

80. Shelton (2014, pp. 139-41). It is the nature of environmental problems that their polycentricity requires 'a rich variety of normative strategies, both formal and 
informal': see Toope (2007, pp. 115-16). See, on the variety of motivators behind opting for a soft law instrument instead of a hard law instrument, Shelton (2003, pp. 12-13).

81. Shelton (2003, p. 4): 'Some soft law instruments may have a specific normative content that is "harder" than the soft commitments in treaties'. Effectiveness is closely linked to compliance, which is subject to the institutional setting cultural differences and regional diversity, type of obligations (requiring positive actions or abstention) and specificity of the obligation: see Shelton (2003, pp. 3-4, 13-17).

82. Driftnet fishing is a particularly harmful means of fishing as it relies on up to 50-km-long nets, which typically lead to the catching of a wide variety of marine wildlife of which up to 40 per cent is discarded. Furthermore, driftnet fishing causes harm to navigation: see Rothwell (2003, pp. 122-3).

83. UNGA Res. 44/225 (1989).

84. UNGA Res. 45/197 (1990) and UNGA Res. 46/215 (1991).

85. UNGA Res. 46/215 (1991). Since then the sustainability of driftnet fishing has been an annual concern for the General Assembly resulting in a series of resolutions elaborating the ban: see http://www.un.org/depts/los/general_assembly/general_ assembly_resolutions.htm.

86. Sands et al. (2012, p. 431).

87. Rothwell (2003, pp. 131-44).

88. Rothwell (2003, p. 135).

89. See http://www.nilebasin.org/index.php/about-us/nile-basin-initiative. For a brief description of the history of water (non)cooperation, see Brunnée and Toope (2002, pp. 105-108, 132-7).

90. Ibid. (p. 137). Mekonnen (2010, pp. 425-6) has argued that this change had begun already before the NBI and so the success it has had cannot be fully attributed to it alone.

91. Brunnée and Toope (2002, p. 158): '[A]n assessment of the various informal processes in the Nile Basin illustrates that norms can generate adherence even if they are not formally binding'. See also Toope (2007, p. 119).

92. Agreement on the Nile River Basin Cooperative Framework; http://www.nilebasin. org/images/docs/CFA\%20-\%20English\%20\%20FrenchVersion.pdf.

93. See http://www.nilebasin.org/index.php/spotlight/99-cfa-overview.

94. The Cooperative Framework Agreement has been ratified by three countries (Ethiopia, Rwanda and Tanzania). Under art. 43 of the Agreement, the framework enters into force on the sixtieth day following the date of deposit of the sixth instrument of ratification or accession with the African Union.

95. See http://unfccc.int/kyoto_protocol/mechanisms/clean_development_mechanism/ items/2718.php.

96. UN Doc. FCCC/KP/CMP/2005/8/add.1, 30 March 2006.

97. For a brief description, see Kulovesi (2013, p. 36).

98. Ibid.

99. For an overview, see http://echa.europa.eu/web/guest/regulations/reach/ understanding-reach.

100. See European Chemical Agency Guidance on Data Sharing, Version 2.0, April 2012, p. 3.

101. Korkea-Aho (2013, p. 367): 'Guidance documents are primarily technical notes on different aspects of REACH, but this says little about how they are applied in normative and practical contexts. The main text of REACH makes no reference to guidance documents; they are classic soft law material. They shirk binding commitments: the cover page of each REACH guidance document reads "the information in this document does not constitute legal advice". Nonetheless, they rule in practice'. 
102. See Grnchalla-Wesierski (1984, pp. 52-7); Shelton (2003, p. 1).

103. See on the catalytic effect of soft law, Shelton (2003, p. 4).

104. See on a general level, Shelton (2003, p. 10). See on the interpretative effect of soft law, Fastenrath (1993, p. 339). Soft law can either strengthen the normative basis of hard law or delegitimise it. See on the delegitimising effect of soft law, GrnchallaWesierski (1984, pp. 52-7).

105. As Toope (2007, p. 114) observes: '[f]ormal and informal approaches to shaping behaviour are therefore inextricably intertwined. Nowhere is this more apparent than in the range of issue areas brought together under international environmental law'. See also ibid (p. 124): 'Formal and informal norms operate side by side. Each can be influential and each can fail to influence'.

106. Soft law can be used for evoking mutual understanding, good faith and voluntary compliance but without the formal legal obligation as a mechanism of compliance: see Boyle (2014, p. 120).

107. Despite this, the independence of soft law from hard law is a matter of degree. In the case of UN General Assembly (UNGA) driftnet resolutions, there is a hard mandate for the UNGA to establish normative guidelines. Similarly with regards to the NBI, governance of the Nile river basin was covered to a certain extent by hard law even before the initiative making the NBI partially linked to hard law. The CDM also has art. 12 of the Kyoto Protocol as its normative basis. Finally, with regard to REACH, the European chemicals legislation is based on hard law but is being complemented by soft law interpretatively. These linkages between formal and non-formal instruments suggest a close relationship between law and non-law rather than independence.

108. Hillgenberg (1999, p. 515).

109. Abbott et al. (2000, p. 401).

110. This is clearly visible in Sands et al.'s (2012, pp. 187-8) description of evaluating the normativity of legal principles. Application of a principle depends on 'the source of the principle; its textual content and language; the particular activity at issue; the environmental and other consequences of the activity; and the circumstances in which it occurs (including the actors and the geographical region)'.

111. Separating material and formal sources of law similarly to Thirlway (2014, pp. 92-3), one can argue that formally binding sources need not embrace material rights and obligations. The same is true in reverse: informal sources can sometimes function as sources of material rights and obligations. Applying d'Aspremont (2008, pp. 1081-7) in separating between instrumentum (source of normative obligation) and negotium (content of the obligation), hard law is hard in instrumentum but can be soft in negotium. In contrast, soft law is soft instrumentum but can be hard in negotium.

112. Brunnée and Toope (2002, p. 115): '[T]here are certain internal characteristics that distinguish law from other forms of social ordering. They may be summarized as requiring that rules be compatible with one another, that they ask reasonable things, that they are transparent and relatively predictable, and that known rules actually guide the discretion of officials. It is these internal characteristics that account for the "bindingness" of law, rather than hierarchical authority or pedigree'. Softening this message somewhat leads to normativity being based on tripartite criteria: form, legitimacy and effectiveness. Shaffer and Pollack (2010, p. 716) and Vihma (2013, p. 162) have talked about the legislation continuum meaning the partial blurring of the criterion for normativity. 


\section{REFERENCES}

Aarnio, Aulis, Robert Alexy and Aleksander Peczenik (1992), 'The Foundation of Legal Reasoning' in Aulis Aarnio and Neil MacCormick (eds), Legal Reasoning Volume 1 (Aldershot, Dartmouth), pp. 15-40, 233-81.

Abbott, Kenneth W., Robert O. Keohane, Andrew Moravcsik, Anne-Marie Slaughter and Duncan Snidal (2000), 'The Concept of Legalization', International Organisation 54(3), pp. 401-19.

Alexy, Robert (1989), A Theory of Legal Argumentation. The Theory of Rational Discourse as Theory of Legal Justification (Oxford, Clarendon Press).

Alexy, Robert (2010), 'The Dual Nature of Law', Ratio Juris 23(2), pp. 167-82.

Balekjian, W.H. (2015), 'The Language of International Law. Linguistic Considerations Involved in the Drafting and Interpretation of International Legal Instruments'; http:// biblio.juridicas.unam.mx/libros/1/468/35.pdf.

Baxter, R.R. (1980), 'International Law "in Her Infinite Variety", International \& Comparative Law Quarterly 29, pp. 549-66.

Beyerlin, Ulrich (2007), 'Different Types of Norms in International Environmental Law. Policies, Principles and Rules' in Daniel Bodansky, Jutta Brunnée and Ellen Hey (eds), The Oxford Handbook of International Environmental Law (Oxford, Oxford University Press), pp. 423-48.

Beyerlin, Ulrich and Thilo Marauhn (2011), International Environmental Law (Oxford, Hart Publishing).

Birnie, Patricia, Alan Boyle and Catherine Redgwell (2009), International Law and the Environment (3rd edn, Oxford, Oxford University Press).

Bodansky, Daniel (1993), 'The United Nations Framework Convention on Climate Change: A Commentary', Yale Journal of International Law 18, pp. 451-558.

Bosselmann, Klaus (2013), 'Grounding the Rule of Law' in Christina Voigt (ed.), Rule of Law for Nature. New Dimensions and Ideas in Environmental Law (Cambridge, Cambridge University Press), pp. 75-93.

Boyle, Alan (2014), 'Soft Law in International Law-making' in Malcom D. Evans (ed.), International Law (4th edn, Oxford, Oxford University Press), pp. 118-36.

Brunnée, Jutta and Stephen J. Toope (2002), 'The Changing Nile Basin Regime: Does Law Matter?', Harvard International Law Journal 43(1), pp. 105-59.

Bugge, Hans Christian (2013), 'Twelve fundamental challenges in environmental law. An Introduction to the concept of rule of law for nature' in Christina Voigt (ed.), Rule of Law for Nature. New Dimensions and Ideas in Environmental Law (Cambridge, Cambridge University Press), pp. 3-26.

d'Aspremont, Jean (2008), 'Softness in International Law: A Self-Serving Quest for New Legal Materials', European Journal of International Law 19(5), pp. 1075-93.

Dorbeck-Jung, Bärbel and Marloes van Amerom (2008), 'The Hardness of Soft Law in the United Kingdom: State and Non-State Regulatory Activities Related to Nanotechnological Development' in Hanneke van Schooten and Jonathan Verschuuren, International Governance and Law. State Regulation and Non-state Law (Cheltenham, Edward Elgar Publishing), pp. 129-50.

Dworkin, Ronald (1978), Taking Rights Seriously (Cambridge, MA, Harvard University Press).

Fastenrath, Ulrich (1993), 'Relative Normativity in International Law', European Journal of International Law 4, pp. 305-40.

Fisher, Douglas (2013), Legal Reasoning in Environmental Law. A Study of Structure, Form and Language (Cheltenham, Edward Elgar Publishing). 
Friedrich, Jürgen (2013), International Environmental 'Soft Law'. The Functions and Limits of Nonbinding Instruments in International Environmental Governance and Law (Heidelberg, New York, Springer).

Grnchalla-Wesierski, Tadensz (1984), 'A Framework for Understanding "Soft Law", McGill Law Journal 30, pp. 37-88.

Hart, H.L.A. (1994), The Concept of Law (2nd edn, Oxford, Oxford University Press).

Hey, Ellen (2007), 'International Institutions' in Daniel Bodansky, Jutta Brunnée and Ellen Hey (eds), The Oxford Handbook of International Environmental Law (Oxford, Oxford University Press), pp. 749-69.

Hillgenberg, Hartmut (1999), 'A Fresh Look at Soft Law', European Journal of International Law 10, pp. 499-515.

Klabbers, Jan (1996), 'The Redundancy of Soft Law', Nordic Journal of International Law 65, pp. 167-82.

Korkea-Aho, Emilia (2013), 'Laws in Progress? Reconceptualizing Accountability Strategies in the Era of Framework Norms', Transnational Environmental Law 2(2), pp. 363-85.

Koskenniemi, Martti (1997), 'Hierarchy in International Law: A Sketch', European Journal of International Law 8, pp. 566-82.

Koskenniemi, Martti (2005), From Apology to Utopia. The Structure of International Legal Argument (Cambridge, Cambridge University Press).

Koskenniemi, Martti (2014), 'What is International Law For?' in Malcom D. Evans (ed.), International Law (4th edn, Oxford, Oxford University Press), pp. 29-52.

Kotzé, Louis (2012), Global Environmental Governance. Law and Regulation for the 21st Century (Cheltenham, Edward Elgar Publishing).

Kotzé, Louis (2013), 'Sustainable development and rule of law for nature' in Christina Voigt (ed.), Rule of Law for Nature. New Dimensions and Ideas in Environmental Law (Cambridge, Cambridge University Press), pp. 130-45.

Kress, Ken (2003), 'Legal Indeterminacy' in Dennis Patterson (ed.), An Anthology of Philosophy of Law and Legal Theory (Malden, MA, Oxford, Melbourne, Berlin, Blackwell Publishing), pp. 253-91.

Kulovesi, Kati (2013), 'Exploring the Landscape of Climate Law and Scholarship: Two Emerging Trends' in Erkki J. Hollo, Kati Kulovesi and Michael Mehling (eds), Climate Change and the Law (Dordrecht, Heidelberg, New York, London, Springer), pp. 31-62.

Leiter, Brian (2001), 'Legal Realism and Legal Positivism Reconsidered', Ethics 111(2), pp. 278-301.

MacCormick, Neil and Robert S. Summers (1991), 'Interpretation and Justification' in Neil MacCormick and Robert S. Summers (eds), Interpreting Statutes. A Comparative Study (Dartmouth, Ashgate Publishing), pp. 511-44.

Mekonnen, Dereje Zeleke (2010), 'The Nile Basin Cooperative Framework Agreement Negotiations and the Adoption of a "Water Security" Paradigm: Flight into Obscurity or a Logical Cul-de-sac?', European Journal of International Law 21(2), pp. 421-40.

Peczenik, Aleksander (1989), On Law and Reason (Dordrecht, Kluwer Academic Publishers).

Petman, Jarna (2012), Human Rights and Violence. The Hope and the Fear of the Liberal World (Helsinki, University of Helsinki).

Redgwell, Catherine (2014), 'International Environmental Law' in Malcom D. Evans (ed.), International Law (4th edn, Oxford, Oxford University Press), pp. 688-726.

Rothwell, Donald R. (2003), 'The General Assembly Ban on Driftnet Fishing' in Dinah Shelton (ed.), The Role of Non-binding Norms in the International Legal System (Oxford, Oxford University Press), pp. 121-46.

Russel, Bertrand (1998), The Problems of Philosophy. Introduction by John Skorupski (2nd edn, Oxford, Oxford University Press). 


\section{Research handbook on fundamental concepts of environmental law}

Sands, Philippe, Jacqueline Peel, Adriana Fabra and Ruth Mackenzie (2012), Principles of International Environmental Law (3rd edn, Cambridge, Cambridge University Press).

Shaffer, Gregory C. and Pollack, Mark A. (2010), 'Hard vs. Soft Law: Alternatives, Complements, and Antagonists in International Governance', Minnesota Law Review 94, pp. 706-99.

Shelton, Dinah (2003), "Introduction: Law, Non-Law and the Problem of "Soft Law" in Dinah Shelton (ed.), The Role of Non-binding Norms in the International Legal System (Oxford, Oxford University Press), pp. 1-20.

Shelton, Dinah (2014), 'International Law and "Relative Normativity"' in Malcom D. Evans (ed.), International Law (4th edn, Oxford, Oxford University Press), pp. 137-65.

Singer, Joseph (1984), 'The Player and the Cards: Nihilism and Legal Theory', Yale Law Journal 94(1), pp. 1-70.

Summers, Robert S. (1982), Instrumentalism and American Legal Theory (Ithaca, London, Cornell University Press).

Thirlway, Hugh (2014), 'The Sources of International Law' in Malcom D. Evans (ed.), International Law (4th edn, Oxford, Oxford University Press), pp. 91-136.

Toope, Stephen J. (2007), 'Formality and Informality' in Daniel Bodansky, Jutta Brunnée and Ellen Hey (eds), The Oxford Handbook of International Environmental Law (Oxford, Oxford University Press), pp. 107-24.

Verschuuren, Jonathan (2003), Principles of Environmental Law. The Ideal of Sustainable Development and the Role of Principles of International, European and National Environmental Law (Baden-Baden, Nomos Verlagsgesellschaft).

Vihma, Antto (2013), 'Analyzing Soft Law and Hard Law in Climate Change' in Erkki J. Hollo, Kati Kulovesi and Michael Mehling (eds), Climate Change and the Law (Dordrecht, Heidelberg, New York, London, Springer), pp. 143-64.

Voigt, Christina (2013), 'The Principle of Sustainable Development. Integration and Ecological Integrity' in Christina Voigt (ed.), Rule of Law for Nature. New Dimensions and Ideas in Environmental Law (Cambridge, Cambridge University Press), pp. 146-57.

Weil, Prosper (1983), 'Towards Relative Normativity in International Law?', American Journal of International Law 77, pp. 413-42.

Weinberger, Ota and Christiane Weinberger (1979), Logik, Semantik, Hermeneutik (München, C.H. Beck'sche Verlagsbuchhandlung).

\section{INSTRUMENTS}

Continental Shelf Convention: Geneva, 29 April 1958, in force 10 June 1964, 499 United Nations Treaty Series, p. 311.

Convention on Biological Diversity: Rio de Janeiro, 5 June 1992, in force 29 December 1993, 31 International Legal Materials (1992), p. 818.

Convention on the Law of the Non-navigational Uses of International Watercourses: New York, 21 May 1997, in force 17 August 2014, 36 International Legal Materials (1998), p. 700 .

Framework Convention on Climate Change: Rio de Janeiro, 9 May 1992, in force 21 March 1993, 31 International Legal Materials (1992), p. 849.

Kyoto Protocol to the United Nations Framework Convention on Climate Change: Kyoto, 10 December 1997, in force 16 February 2005, 37 International Legal Materials (1998), p. 22.

Regulation No 1907/2006 of the European Parliament and of the Council of 18 December 2006 concerning the Registration, Evaluation, Authorisation and Restriction of Chemicals (REACH), establishing a European Chemicals Agency, amending Directive 
1999/45/EC and repealing Council Regulation (EEC) No 793/93 and Commission Regulation (EC) No 1488/94 as well as Council Directive 76/769/EEC and Commission Directives 91/155/EEC, 93/67/EEC, 93/105/EC and 2000/21/EC, OJ L 396/1.

Vienna Convention on the Law of Treaties: Vienna, 23 May 1969, in force 27 January 1980, 1155 United Nations Treaty Series, p. 331.

Vienna Convention for the Protection of the Ozone Layer: Vienna, 22 March 1985, in force 22 September 1988, 26 International Legal Materials (1986), p. 1529.

\section{CASES}

Danube Dam case: 25 September 1997 (Hungary v. Slovakia) ICJ Rep., 37 International Legal Materials (1998).

Lotus case: 7 September 1927 (France v. Turkey) Publications of the Permanent Court of International Justice, Series A - No. 10.

North Sea Continental Shelf case: 20 February 1969 (Germany v. Denmark and the Netherlands) ICJ Rep. 